INTERNATIONAL JOURNAL OF RESEARCHES IN BIOSCIENCES, AGRICULTURE AND TECHNOLOGY C VISHWASHANTI MULTIPURPOSE SOCIETY (Global Peace Multipurpose Society) R. No. MH-659/13(N) wWw.ijrbat.in

\title{
EVALUATION OF PHYSICO-CHEMICAL PARAMETERS OF RIVER KRISHNA AND RIVER VENNA, IN DISTRICT SATARA, MAHARASHTRA, INDIA.
}

\author{
Sawant Pratibha L ., *Patil R G., **Dubal R. S., ${ }^{* * * B h o l e ~ N . B . ~}$ \\ *Emeritus fellow and Research Director, Department of Zoology, \\ Lal Bahadur Shastri College of Arts, Science and Commerce, Satara(M.S.) \\ **Department of Zoology, Yashavantrao Chavan Institute of Science, Satara (M.S.) \\ ***Head, Department of Civil Engineering, Shree Datta Polytechnic College, Shirol (M.S.)
}

Abstract:

\begin{abstract}
Satara district has a rich network of rivers and rivers provide us water for drinking and agricultural purposes. The present investigation deals with the physico-chemical parameters of Krishna and Venna rivers to investigate the quality of river water. The physico-chemical parameters of Krishna and Venna rivers such as $\mathrm{pH}$, temperature, hardness, total dissolved solids, phosphate, nitrate, chloride, alkalinity, $\mathrm{DO}, \mathrm{CO}_{2}$ were observed and analyzed from August 2012 to July 2013 at every month. The physicochemical parameters of river Krishna such as $\mathrm{pH}$, temperature, nitrate, hardness, chloride, TDS are within permissible limit of WHO and parameters such as alkalinity, phosphate, $\mathrm{DO}, \mathrm{CO}_{2}$ are exceeded the recommended limit of WHO. While all the physicochemical parameters except phosphate of river Venna are within the recommended limits of WHO.
\end{abstract}

Keywords: Physico-chemical, Krishna River, Venna River, Wai, Medha, Water Quality.

\section{Introduction}

Rivers provide us water, transportation and a means of disposal whereas it is natural ecosystem most intensely used by humans. The characters of rivers changes from its source to mouth. Two rivers or portions of two rivers are not identical in all aspects. Each section of a river is unique in several aspects and calls upon for an investigation (Goel and Autade, 1995).

Satara district (Maharashtra-India) has a rich network of rivers. The main rivers of Satara district are Koyana and Krishna. The Krishna is one of the third largest sacred rivers of southern India. The Krishna river has its origin in Mahabaleshwar. Krishna water is mainly used for drinking and agricultural purpose while it is also used for industrial purposes. These industries include cement, acexto, fertilizers, iron, alcoholic product, vegetable oil,dye-chem. Industries and sugarcane industries which are also situated in the close vicinity of the Krishna river. The waste water from towns and industrial effluents from M.I.D.C's and sugarcane industries get entered in the Krishna river. Venna river is also originated in Mahabaleshwar, as a tributary of river Krishna. Krishna and Venna rivers run parallel to each other through Satara tahsil.

Remarkable contributions are made in the field of limnology, hydrobiology and environmental quality of lotic aquatic environment by Iyengar (1939), Gonzalves and Joshi (1946), Chacko and Krishnamurthy (1954), Rao (1955), Das and Srivastava (1956), Ahmed (1966), Khan and Quayyam (1966).

\section{Materials and Methods}

The physicochemical parameters of river Krishna and river Venna was studied for one complete year, from August 2012 to July 2013. The water samples of river Krishna at sampling station Wai and the water samples of river Venna at sampling station Medha were collected in the Morning Hours between 9.00 a.m. to 12.00 noon throughout the study period. Two litre polythene ( stoppered ) cans were used for collection of water samples. The water samples were immediately brought into laboratory for the analysis of physico-chemical parameters. Some of the parameters such as $\mathrm{pH}$ and temperature were recorded at time of sample collection by using thermometer and standard $\mathrm{pH}$ meter, where as the other parameters such as Hardness , TDS, Phosphate, Nitrate, Chloride, Alkalinity, DO, $\mathrm{CO}_{2}$ were estimated by using standard methods described by APHA ( 1985 ), Trivedy and Goel ( 1986), Kodarkar (2006).

\section{Result and Discussion:}

Monthly variations in physico-chemical parameters of river Krishna at sampling station Wai from August 2012 to July 2013 were recorded in Table No.1 and monthly variations in physico-chemical parameters of river Venna at sampling station Medha from August 2012 to July 2013 were recorded in Table No.2.

\section{OBSERVATIONS}
A) Observations on Physico-chemical
parameters of the water in Krishna River. 
Table No.1: Monthly variations in Physico-chemical parameters of the Krishna River at sampling station -Wai (Year 2012-13)

\begin{tabular}{|c|c|c|c|c|c|c|c|c|c|c|c|c|c|}
\hline \multirow[b]{2}{*}{$\begin{array}{c}\text { Physicochemical } \\
\text { Parameters }\end{array}$} & \multicolumn{12}{|c|}{ Months } & \multirow{2}{*}{$\begin{array}{c}\text { Mean and } \\
\pm \text { S.D. }\end{array}$} \\
\hline & Aug & Sept & Oct & Nov & Dec & Jan & Feb & Mar & Apr & May & Jun & July & \\
\hline pH & 7.50 & 7.40 & 7.40 & 7.30 & 7.20 & 7.10 & 7.60 & 7.80 & 7.80 & 8.20 & 7.50 & 7.30 & $7.51 \pm 0.31$ \\
\hline Temperature $\left({ }^{\circ} \mathrm{C}\right)$ & 23.00 & 23.80 & 23.60 & 22.70 & 21.20 & 18.20 & 23.20 & 26.80 & 29.50 & 31.60 & 28.30 & 27.40 & $24.94 \pm 3.82$ \\
\hline Hardness (ppm) & $\begin{array}{c}245.0 \\
0\end{array}$ & $\begin{array}{c}240.0 \\
0\end{array}$ & $\begin{array}{c}220.0 \\
0\end{array}$ & $\begin{array}{c}215.0 \\
0\end{array}$ & 185.0 & 132.0 & 189.0 & $\begin{array}{c}220.0 \\
0\end{array}$ & 240.0 & $\begin{array}{c}239.0 \\
0\end{array}$ & $\begin{array}{c}270.0 \\
0\end{array}$ & $\begin{array}{c}253.0 \\
0\end{array}$ & $\begin{array}{c}220.67 \pm 37.3 \\
3\end{array}$ \\
\hline $\begin{array}{l}\text { Tota } \\
\text { Solid }\end{array}$ & 0.34 & 0.33 & .33 & 28 & 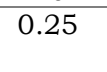 & 20 & 32 & 36 & 37 & 39 & 33 & 41 & $0.33 \pm 0$ \\
\hline Phosphate (ppm) & 7.40 & 7.20 & 7.20 & 7.00 & 6.70 & 5.60 & 6.50 & 7.90 & 8.30 & 9.10 & 8.70 & 7.70 & $7.4 \pm 0.98$ \\
\hline Nitrate (ppm) & 11.20 & 13.00 & 13.20 & 16.70 & 20.00 & 21.50 & 16.80 & 10.40 & 8.90 & 7.80 & 9.50 & 10.60 & $13.30 \pm 4.47$ \\
\hline Chloride (ppm) & 41.00 & 38.00 & 32.00 & 23.00 & 18.00 & 20.20 & 28.50 & 35.40 & 40.50 & 45.50 & 47.30 & 45.00 & $34.53 \pm 10.17$ \\
\hline Alkalinity (ppm & $\begin{array}{c}237.0 \\
0\end{array}$ & $\begin{array}{c}232.0 \\
0\end{array}$ & $\begin{array}{c}220.0 \\
0\end{array}$ & $\begin{array}{c}210.0 \\
0\end{array}$ & $\begin{array}{c}225.0 \\
0\end{array}$ & $\begin{array}{c}228.0 \\
0\end{array}$ & $\begin{array}{c}228.0 \\
0\end{array}$ & $\begin{array}{c}239.0 \\
0\end{array}$ & $\begin{array}{c}250.0 \\
0\end{array}$ & $\begin{array}{c}260.0 \\
0\end{array}$ & $\begin{array}{c}274.0 \\
0\end{array}$ & $\begin{array}{c}238.0 \\
0\end{array}$ & $\begin{array}{c}236.75 \pm 17.6 \\
3\end{array}$ \\
\hline DO (ppm) & 6.40 & 6.10 & 5.90 & 5.20 & 5.00 & 5.80 & 6.10 & 6.80 & 7.30 & 7.60 & 7.90 & 7.40 & $6.46 \pm 0.95$ \\
\hline $\mathrm{CO}_{2}$ (ppm) & 19.00 & 17.80 & 15.40 & 12.90 & 11.00 & 9.20 & 12.30 & 17.50 & 18.90 & 22.40 & 21.20 & 20.30 & $16.49 \pm 4.28$ \\
\hline
\end{tabular}

B) Observations on Physico-chemical parameters of the water in Venna River.

Table No.2. Monthly variations in Physico-chemical parameters of the Venna River at sampling station -Medha (Year 2012-13).

\begin{tabular}{|c|c|c|c|c|c|c|c|c|c|c|c|c|c|}
\hline \multirow[b]{2}{*}{$\begin{array}{l}\text { Physicochemical } \\
\text { Parameters }\end{array}$} & \multicolumn{12}{|c|}{ Months } & \multirow{2}{*}{$\begin{array}{c}\text { Mean and } \\
\pm \text { S.D. }\end{array}$} \\
\hline & Aug & Sept & Oct & Nov & Dec & Jan & Feb & Mar & Apr & May & Jun & July & \\
\hline pH & 7.10 & 7.10 & 6.80 & 6.60 & 6.70 & 6.30 & 6.90 & 6.80 & 7.40 & 7.60 & 7.50 & 7.20 & $7.00 \pm 0.39$ \\
\hline Temperature $\left({ }^{\circ} \mathrm{C}\right)$ & 21.00 & 21.50 & 21.00 & 20.00 & 19.00 & 17.00 & 22.00 & 24.70 & 26.70 & 28.20 & 27.90 & 26.40 & $22.95 \pm 3.71$ \\
\hline Hardness (ppm) & 45.00 & 49.00 & 45.00 & 40.00 & 37.30 & 31.60 & 38.50 & 43.20 & 45.00 & 48.00 & 57.00 & 47.00 & $43.88 \pm 6.52$ \\
\hline $\begin{array}{l}\text { Total Dissolved } \\
\text { Solids (gm/lit) }\end{array}$ & 0.11 & 0.11 & 0.11 & 0.10 & 0.10 & 0.09 & 0.17 & 0.19 & 0.23 & 0.20 & 0.21 & 0.30 & $0.16 \pm 0.07$ \\
\hline Phosphate (ppm) & 6.00 & 5.40 & 5.00 & 5.20 & 3.30 & 3.00 & 4.80 & 5.50 & 6.70 & 7.10 & 7.00 & 6.50 & $5.46 \pm 1.33$ \\
\hline Nitrate (ppm) & 7.90 & 8.40 & 9.10 & 10.00 & 10.50 & 10.80 & 8.90 & 7.10 & 6.50 & 5.80 & 6.70 & 7.20 & $8.24 \pm 1.65$ \\
\hline Chloride (ppm) & 15.00 & 12.40 & 8.00 & 7.50 & 6.00 & 6.40 & 7.60 & 9.30 & 12.80 & 15.50 & 16.30 & 16.20 & $11.08 \pm 4.03$ \\
\hline Alkalinity (ppm) & 36.50 & 33.00 & 35.00 & 33.00 & 37.00 & 36.90 & 38.10 & 40.00 & 45.30 & 50.00 & 51.30 & 44.20 & $40.19 \pm 6.26$ \\
\hline DO (ppm) & 12.10 & 11.00 & 9.00 & 8.60 & 7.90 & 8.40 & 9.60 & 10.70 & 12.40 & 13.70 & 14.90 & 13.40 & $10.98 \pm 2.33$ \\
\hline $\mathrm{CO}_{2}$ (ppm) & 9.00 & 8.50 & 7.90 & 7.20 & 7.00 & 6.70 & 7.60 & 12.00 & 13.60 & 15.00 & 12.20 & 10.00 & $9.73 \pm 2.81$ \\
\hline
\end{tabular}

Table No.3. Comparative study of observed parameters in river Krishna and Venna with WHO

\begin{tabular}{|c|c|c|c|c|c|c|}
\hline \multirow[t]{2}{*}{ Sr.No. } & \multirow{2}{*}{$\begin{array}{l}\text { Physico-chemical } \\
\text { parameters }\end{array}$} & \multicolumn{2}{|c|}{ Observed Maximum Value } & \multicolumn{2}{|c|}{ Observed Minimum Value } & \multirow[t]{2}{*}{ WHO limits } \\
\hline & & $\begin{array}{c}\text { Krishna } \\
\text { River (Wai) }\end{array}$ & $\begin{array}{l}\text { Venna River } \\
\text { (Medha) }\end{array}$ & $\begin{array}{c}\text { Krishna } \\
\text { River (Wai) }\end{array}$ & $\begin{array}{l}\text { Venna River } \\
\text { (Medha) }\end{array}$ & \\
\hline 1 & $\mathrm{pH}$ & 8.20 & 7.60 & 7.10 & 6.30 & $6.5-9.2$ \\
\hline 2 & Temperature $\left({ }^{\circ} \mathrm{C}\right)$ & 31.60 & 28.20 & 18.20 & 17.00 & $40^{\circ} \mathrm{C}$ \\
\hline 3 & Hardness (mg/l) & 270.00 & 57.00 & 132.00 & 31.60 & $\begin{array}{c}100-500 \\
\mathrm{mg} / 1\end{array}$ \\
\hline 4 & $\begin{array}{l}\text { Total Dissolved } \\
\text { Solids (gm/lit) }\end{array}$ & 0.41 & 0.30 & 0.20 & 0.09 & $\begin{array}{c}500-1500 \\
\mathrm{mg} / 1\end{array}$ \\
\hline 5 & Phosphate (mg/1) & 9.10 & 7.10 & 5.60 & 3.00 & $0.1 \mathrm{mg} / 1$ \\
\hline 6 & Nitrate $(\mathrm{mg} / \mathrm{l})$ & 21.50 & 10.80 & 7.80 & 5.80 & $45 \mathrm{mg} / 1$ \\
\hline 7 & Chloride (mg/l) & 47.30 & 16.30 & 18.00 & 6.00 & $\begin{array}{c}200-600 \\
\mathrm{mg} / 1\end{array}$ \\
\hline 8 & Alkalinity (mg/1) & 274.00 & 51.30 & 210.00 & 33.00 & $250 \mathrm{mg} / 1$ \\
\hline 9 & $\mathrm{DO}(\mathrm{mg} / \mathrm{l})$ & 7.90 & 14.90 & 5.00 & 7.90 & $5-7 \mathrm{mg} / 1$ \\
\hline 10 & $\mathrm{CO}_{2}(\mathrm{mg} / 1)$ & 22.40 & 15.00 & 9.20 & 6.70 & $22 \mathrm{mg} / 1$ \\
\hline
\end{tabular}


In present investigation $\mathrm{pH}$ of river Krishna was highest 8.20 in the month of May and lowest 7.10 in the month of January and pH of river Venna was highest 7.60 in the month of May and lowest 6.30 in the month of January. Medera et al. reported that the $\mathrm{pH}$ of natural water ranges from 6.5-8.5. The water temperature of river Krishna ranges $31.600 \mathrm{C}$ (May) to $18.200 \mathrm{C}$ (January) and the water temperature of river Venna ranges 28.200C (May) to $17.000 \mathrm{C}$ (January). The fluctuations in water temperature may be due to influence of season and different timing of collection (Jayaraman et. al.,2003).

In present study hardness of river Krishna was highest $270.00 \mathrm{mg} / 1$ in June and lowest $132.00 \mathrm{mg} / 1$ in November and hardness of river Venna was highest $57.00 \mathrm{mg} / 1$ in June and lowest $31.60 \mathrm{mg} / 1$ in November. Total hardness was high during summer than monsoon and winter reported by Hujare (2008). The maximum TDS value of river Krishna was $0.41 \mathrm{gm} / 1$ in July and minimum $0.20 \mathrm{gm} / 1$ in January and maximum TDS value of river Venna was $0.30 \mathrm{gm} / 1$ in July and minimum $0.09 \mathrm{gm} / 1$ in January. Increase in value TDS indicated pollution by extraneous sources (Kataria et al. 1996).

The phosphate content in river Krishna was found to be $9.10 \mathrm{mg} / 1 \mathrm{in}$ May and $5.60 \mathrm{mg} / 1 \mathrm{in}$ January and the phosphate content in river Venna was found to be $7.10 \mathrm{mg} / 1$ in May and $3.00 \mathrm{mg} / 1$ in January. Similar observation has been reported by Kamal et al. (2007) in their study on Mouri river. The level of nitrate in river Krishna was maximum $21.50 \mathrm{mg} / 1$ in January and minimum $7.80 \mathrm{mg} / 1$ in May and the level of nitrate in river Venna was maximum $10.80 \mathrm{mg} / 1$ in January and 5.80 $\mathrm{mg} / 1$ in May. The higher limit of chloride in river Krishna was $47.3 \mathrm{mg} / 1$ in June and $18.00 \mathrm{mg} / 1$ in December and the higher limit of chloride in river Venna was $16.30 \mathrm{mg} / 1$ in June and $6.00 \mathrm{mg} / 1$ in December. Higher concentration of chlorides indicates higher degree of organic pollution.( Munawar, 1970).

The maximum alkalinity value of river Krishna was recorded in the month of June $274.00 \mathrm{mg} / 1$ and minimum in the month of November $210.00 \mathrm{mg} / 1$ and the maximum alkalinity value of river Venna was recorded in the month of June $51.30 \mathrm{mg} / 1$ and minimum in the month of November $33.00 \mathrm{mg} / 1$. Das and Pandey (1978) reported that high alkalinity indicates pollution. In this study DO of Krishna river was highest $7.90 \mathrm{mg} / 1$ in June and lowest $5.00 \mathrm{mg} / 1$ in December and DO of
Venna river was highest $14.90 \mathrm{mg} / 1$ in June and lowest $7.90 \mathrm{mg} / 1$ in December. DO indicate the quality of water and organic pollution in the water body (Wetzel and Likens, 2006). CO 2 of river Krishna was $22.40 \mathrm{mg} / 1$ in May and $9.20 \mathrm{mg} / 1$ in January and CO2 of river Venna was $15.00 \mathrm{mg} / 1$ in May and 6.70 $\mathrm{mg} / 1$ in January. When the organic matter content of sewage in water was higher then it reduces oxygen content of water (Ragothaman and Trivedy,2002).

\section{Conclusion:}

The various physico-chemical parameters studied on Krishna river at sampling station Wai and on Venna river at sampling station Medha shows seasonal variations. The physicochemical parameters of river Krishna such as $\mathrm{pH}$, temperature, nitrate, hardness, chloride, TDS are fall within a permissible limit of WHO and parameters such as alkalinity, phosphate, $\mathrm{DO}, \mathrm{CO}_{2}$ are exceeded the recommended limit of WHO. While all the physicochemical parameters except phosphate of river Venna are within the recommended limits of WHO.

\section{References:}

Ahmed,Q.,1966. Water quality and soil condition of fish ponds in relation to fish production. Ind. J. Fish. 13 (1) : 115-119.

APHA- AWWA-WPCF (1985) - Standard methods for examination of water and waste water 16 th edition. American Public Health Association, Washington D.C (1985).

Chacko,P.M. and Krishnmurthy, P.I.,1954. On the plankton of three freshwater fish ponds in Madras City, India. Indo pacific fish coun. (UNESCO) :103-107.

Das, S.M. and Pandey, J (1978). Some Physicochemical and biological indicators of pollution in lake, Nainital, Kumaun (U.P.), Indian Journal of Ecology 5(1) 7-16.

Das, S.M. and Srivastava, V.K., 1956. Quantitative studies on the freshwater plankton of the fish tank in Lucknow, India. P roc. Nat. Acad. Sci. 26 : s82-89.

Goel P.K. and Autade V.B.1995. Ecological Studies on the River Panchganga at Kolhapur with Emphasis on Biological Components. Recent Researches in Aquatic Environment (1995) pp. 24-46.

Gonzalves ,E. A. and Joshi, D. B. 1946. Freshwater algae near Bombay.J. Bom.Nat. His. Soc. $46:$ 154-176.

Hujare, M. S. (2008): Seasonal variation of physico-chemical parameters in the perennial tank of Talsande, Maharashtra. Ecotoxicol. Environ. Monit. 18(3): 233-242. 
Iyengar,M.O.P. 1939. Algal problem peculiar to the tropics with special reference to India. Proc. 25th Indian Sci. Cong. 25(4):141-149.

Jayaraman P.R., Ganga Devi T. and VasuenaNaya T. (2003): Water quality studies on Kasmaneriver, Thiruvanthapuram, District, South Kerla, India. Poll.Res.32(1), 89-100.

Kamal D. Khan A.N., Rahman M.A. and Ahamed F.(2007) : Study on the Physicochemical properties of water of Mouri River, Khulna, Bangladesh. Pakistan Journal of Biological Sciences 10(5), 710-717.

Kataria, H.C., H.A. Quereshi, S.A. Iqbal and A.K. Shandilya (1996), Assessment of water quality of Kolar Reservoir in Bhopal ( MP). Pollution Research, 15, pp191-193.

Khan. J. A. and Quayyam, A. 1966. On the ionic composition at five tropical fish ponds of Aligarh (U.P.) India. Hydrobiologia, 28(2) : 195-201.

Kodarkar, M.S.(2006): In: Methodology for water analysis (Physicochemical, Biological and Microbiological) Published by the Secretary, IAAB.

Medera, v., Allen, H.E., and Minear, R.C.(1982), Non metallic constituents: Examination of water Pollution Control. A Reference HandbookPhysical, Chem. Radiol. Exam. 2, 169-357.

Munawar, M., 1970. Limnological studies on fresh water ponds of Hyderabad, India- II, J. Hydrobiologia. 35 : 127-162.

Ragothaman, G. and Trivedi, R.K., (2002).A text book of aquatic ecology. 1st edition, Agrobios Publishing Co., pp.183-184.

Trivedy R.K and Goel P.K., Chemical and Biological Methods for water Pollution Studies, Karad India, (1986).

Wetzel R.G; Likens G.E.(2006). Limnological analysis.3rd ed. Springer-verlag, New York, 391. 